\title{
Synthesis and characterization of a new and electronically unusual uranium metallacyclocumulene, $\left(\mathrm{C}_{5} \mathrm{Me}_{5}\right)_{2} \mathrm{U}\left(\eta^{4}-\right.$ 1,2,3,4-PhC $\left.{ }_{4} \mathrm{Ph}\right)$.
}

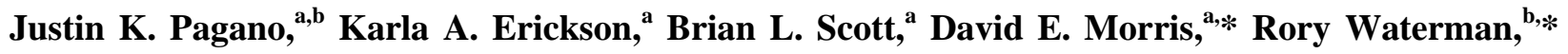 \\ and Jaqueline L. Kiplinger ${ }^{\mathrm{a}, *}$
}

A B S T R A C T

Keywords:

Uranium

Pentamethylcyclopentadienyl

Metallacyclocumulene

Electronic spectroscopy

X-ray crystallography

\begin{abstract}
A new uranium metallacyclocumulene, $\left(\mathrm{C}_{5} \mathrm{Me}_{5}\right)_{2} \mathrm{U}\left(\eta^{4}-\mathrm{PhC}{ }_{4} \mathrm{Ph}\right)$, was synthesized by both reaction of $\left(\mathrm{C}_{5} \mathrm{Me}_{5}\right)_{2} \mathrm{UCl}_{2}$ with 1,4-diphenylbutadiyne in the presence of $\mathrm{KC}_{8}$ and by ligand exchange between $\left(\mathrm{C}_{5} \mathrm{Me}_{5}\right)_{2} \mathrm{U}\left(\eta^{2}-\mathrm{Me}_{3} \mathrm{SiC}_{2} \mathrm{SiMe}_{3}\right)$ and 1,4-diphenylbutadiyne. Full characterization of $\left(\mathrm{C}_{5} \mathrm{Me}_{5}\right)_{2} \mathrm{U}\left(\eta^{4}-\mathrm{PhC}_{4} \mathrm{Ph}\right)$ is reported, including the solid-state structure. $\left(\mathrm{C}_{5} \mathrm{Me}_{5}\right)_{2} \mathrm{U}\left(\eta^{4}-\mathrm{PhC} \mathrm{C}_{4} \mathrm{Ph}\right)$ displays an unusually detailed $\mathrm{UV}$-visible spectrum, which is rare for uranium(IV) metallocene complexes.
\end{abstract}

\section{Introduction}

All-carbon metallacycles feature prominently in organometallic transition metal chemistry, and have been used as precursors to alkylidenes, alkylidynes, vinylidenes, and $\eta^{2}$-vinyl complexes.[1] Metallacyclobutanes and butadienes are intermediates in olefin and alkyne metathesis chemistry,[2-4] while metallacyclopentadienes are used extensively for the synthesis of main group heterocycles and functionalized polymers and organic molecules.[5-8]

Whereas transition metal all-carbon metallacycle chemistry has clearly flourished, the corresponding chemistry for the actinide elements has remained largely unexplored. As illustrated in Scheme 1, only a handful of such metallacycle complexes have been reported for thorium and uranium. In 1981, Marks and co-workers reported the synthesis of the uranium metallacyclopentadiene complex $\left(\mathrm{C}_{5} \mathrm{Me}_{5}\right)_{2} \mathrm{U}\left(\eta^{2}-1,4-\mathrm{C}_{4} \mathrm{Ph}_{4}\right)$ from the reaction of $\left(\mathrm{C}_{5} \mathrm{Me}_{5}\right)_{2} \mathrm{UCl}_{2}$ and two equivalents of $\mathrm{PhC} \equiv \mathrm{CPh}$ with excess reducing equivalents provided by $\mathrm{Na} / \mathrm{Hg},[9]$ and also by salt metathesis between $\left(\mathrm{C}_{5} \mathrm{Me}_{5}\right)_{2} \mathrm{UCl}_{2}$ and 1,4-dilithiotetraphenylbutadiene.[10] Several years later in 2005, the Evans group showed that the sterically crowded complexes $\left(\mathrm{C}_{5} \mathrm{Me}_{5}\right)_{3} \mathrm{U}$, $\left[\left(\mathrm{C}_{5} \mathrm{Me}_{5}\right)_{2} \mathrm{U}\right]\left[(\mu-\mathrm{Ph})_{2} \mathrm{BPh}_{2}\right]$, and $\left[\left(\mathrm{C}_{5} \mathrm{Me}_{5}\right)_{2} \mathrm{U}\right]_{2}\left(\mu-\eta^{6}: \eta^{6}-\right.$ $\left.\mathrm{C}_{6} \mathrm{H}_{6}\right)$ could all reduce $\mathrm{PhC} \equiv \mathrm{CPh}$ to give $\left(\mathrm{C}_{5} \mathrm{Me}_{5}\right)_{2} \mathrm{U}\left(\eta^{2}-\right.$ $\left.1,4-\mathrm{C}_{4} \mathrm{Ph}_{4}\right) \cdot[11]$
In previous work, we showed that treatment of the thorium and uranium alkyl complexes, $\left(\mathrm{C}_{5} \mathrm{Me}_{5}\right)_{2} \mathrm{AnMe}_{2}$ $(\mathrm{An}=\mathrm{Th}, \mathrm{U})$, with 5 and 2 equivalents of $\mathrm{PhSiH}_{3}$ in toluene at $50{ }^{\circ} \mathrm{C}$ afforded the corresponding tetravalent $\left[\left(\mathrm{C}_{5} \mathrm{Me}_{5}\right)_{2} \mathrm{An}(\mu-\mathrm{H})(\mathrm{H})\right]_{2} \quad(\mathrm{An}=\mathrm{Th}, \mathrm{U})$ and trivalent $\left[\left(\mathrm{C}_{5} \mathrm{Me}_{5}\right)_{2} \mathrm{U}(\mathrm{H})\right]_{\mathrm{x}}$ hydride complexes, respectively.[12, 13] These dihydride complexes are known to function as multi-electron reductants,[12-18] Reaction of $\left[\left(\mathrm{C}_{5} \mathrm{Me}_{5}\right)_{2} \mathrm{An}(\mu-\mathrm{H})(\mathrm{H})\right]_{2}(\mathrm{An}=\mathrm{Th}, \mathrm{U})$ with 2 equivalents of $\mathrm{PhC} \equiv \mathrm{CPh}$ produced the corresponding metallacyclopentadiene complexes $\left(\mathrm{C}_{5} \mathrm{Me}_{5}\right)_{2} \mathrm{An}\left(\eta^{2}-1,4-\right.$ $\left.\mathrm{C}_{4} \mathrm{Ph}_{4}\right) \quad(\mathrm{An}=\mathrm{Th}, \mathrm{U}) \cdot[12] \quad$ Similarly, reaction of $\left[\left(\mathrm{C}_{5} \mathrm{Me}_{5}\right)_{2} \mathrm{U}(\mathrm{H})\right]_{\mathrm{x}}$ with 2 equivalents of $\mathrm{PhC} \equiv \mathrm{CPh}$ or $\mathrm{MeC} \equiv \mathrm{CMe}$ gave the uranium metallacyclopentadiene complexes $\left(\mathrm{C}_{5} \mathrm{Me}_{5}\right)_{2} \mathrm{An}\left(\eta^{2}-1,4-\mathrm{C}_{4} \mathrm{R}_{4}\right)(\mathrm{R}=\mathrm{Ph}, \mathrm{Me})$.[13]

During the course of our studies, Walter and co-workers reported the synthesis of $\left(\mathrm{C}_{5} \mathrm{Me}_{5}\right)_{2} \mathrm{Th}\left(\eta^{2}-1,4-\mathrm{C}_{4} \mathrm{Ph}_{4}\right)$ from the reaction of $\left(\mathrm{C}_{5} \mathrm{Me}_{5}\right)_{2} \mathrm{ThCl}_{2}$ and two equivalents of $\mathrm{PhC} \equiv \mathrm{CPh}$ in the presence of excess $\mathrm{KC}_{8} \cdot[19]$ Using similar conditions, these researchers also reported other thorium metallacyclopentadienes, as well as the thorium and uranium metallacyclocumulenes $\left(\mathrm{C}_{5} \mathrm{Me}_{5}\right)_{2} \mathrm{An}\left(\eta^{4}-1,2,3,4-\right.$ $\left.\mathrm{RC}_{4} \mathrm{R}\right)\left(\mathrm{R}=-\mathrm{SiMe}_{3}, \mathrm{An}=\mathrm{Th}, \mathrm{U} ; \mathrm{R}=\mathrm{Ph}, \mathrm{An}=\mathrm{Th}\right)$ and metallacyclopropene complexes $\left(\mathrm{C}_{5}{ }^{\mathrm{t}} \mathrm{Bu}_{3} \mathrm{H}_{2}\right)_{2} \mathrm{Th}\left(\eta^{2}-1,2-\right.$ $\left.\mathrm{PhC}_{2} \mathrm{Ph}\right)$ and $\left(\mathrm{C}_{5} \mathrm{Me}_{5}\right)_{2} \mathrm{U}\left(\eta^{2}-1,2-\mathrm{Me}_{3} \mathrm{SiC}_{2} \mathrm{SiMe}_{3}\right)$. [20-23]

In related work, the Meyer group reported that the uranium(III) complex $\left[\left(\left({ }^{\mathrm{Ad}} \mathrm{ArO}\right)_{3} \mathrm{~N}\right) \mathrm{U}^{\mathrm{III}}(\mathrm{DME})\right]$ reacts with the terminal alkynes 1-hexyne or 4- ${ }^{t}$ butyl-phenylacetylene, 


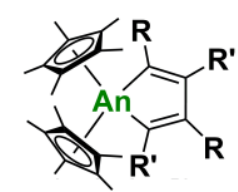

An = Th; R = Ph; R' = Ph, Me, Cy, 'Pr An $=\mathbf{U} ; \mathbf{R}=\mathbf{R}^{\prime}=\mathrm{Ph}, \mathrm{Me}$

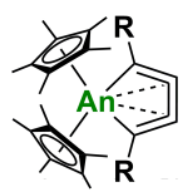

$\mathrm{An}=\mathrm{Th} ; \mathrm{R}=\mathrm{Ph}, \mathrm{SiMe}_{3}$ $A n=U ; R=\mathrm{SiMe}_{3}$

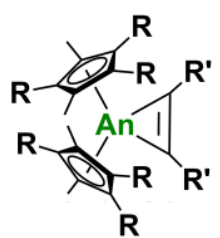

An $=$ Th; $R={ }^{\mathrm{t}} \mathrm{Bu} ; \mathbf{R}^{\prime}=\mathbf{P h}$

$\mathrm{An}=\mathrm{U} ; \mathrm{R}=\mathrm{Me} ; \mathbf{R}^{\prime}=\mathrm{SiMe}_{3}$

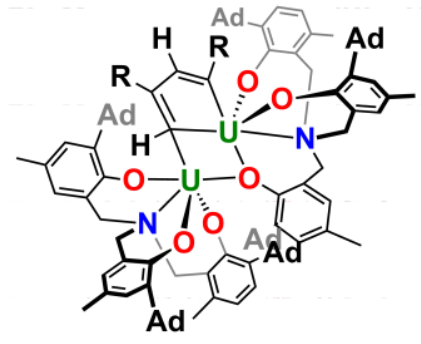

$\mathrm{R}=\boldsymbol{p}-\mathrm{-}^{\mathrm{t}} \mathrm{Bu}-\mathrm{Ph}, \mathrm{Bu}$

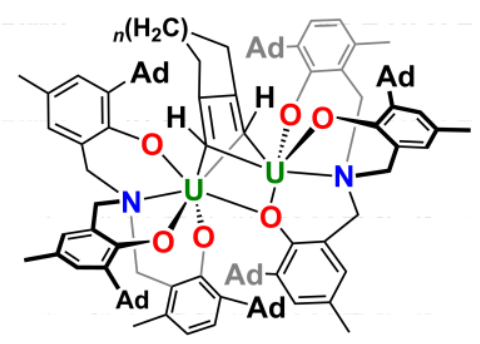

$n=1,2$

Scheme 1. Known examples of actinide complexes featuring all-carbon metallacycle groups.

to give the bimetallic uranium(IV) complexes, $\left[\left\{\left(\left({ }^{\mathrm{Ad}} \mathrm{ArO}\right)_{3} \mathrm{~N}\right) \mathrm{U}^{\mathrm{IV}}\right\}_{2}\left(\mu-\eta^{2}(\mathrm{C} 4): \eta^{1}(\mathrm{C} 1)-1,3-\mathrm{di}-\left(p-{ }^{t} \mathrm{Bu}-\right.\right.\right.$

phenyl)butadiene $))]$ and $\left[\left\{\left(\left({ }^{\mathrm{Ad}} \mathrm{ArO}\right)_{3} \mathrm{~N}\right) \mathrm{U}\right\}_{2}(\mu-\right.$ $\eta^{2}(\mathrm{C} 1): \eta^{1}(\mathrm{C} 4)-2-{ }^{n} \mathrm{Bu}-1,3$-octadiene)], respectively.[24] When the terminal bis-alkynes 1,6-heptadiyne or 1,7octadiyne are employed, the $\mathrm{C}-\mathrm{C}$-coupling reactions proceed to afford the corresponding bicyclic uranium(IV) metallacyclopentadiene derivatives, $\left[\left\{\left(\left({ }^{\mathrm{Ad}} \mathrm{ArO}\right)_{3} \mathrm{~N}\right) \mathrm{U}\right\}_{2}(\mu-\right.$ $\eta^{2}: \eta^{2}-1,2-(C \mathrm{H})_{2}$-cyclopentane $\left.)\right]$ and $\left[\left\{\left({ }^{\mathrm{Ad}} \mathrm{ArO}\right){ }_{3} \mathrm{~N}\right) \mathrm{U}\right\}_{2}(\mu-$ $\eta^{2}: \eta^{1}-1,2-(\mathrm{CH})_{2}$-cyclohexane $\left.)\right]$.

Herein, we report the synthesis and structural characterization of the uranium metallacyclocumulene $\left(\mathrm{C}_{5} \mathrm{Me}_{5}\right)_{2} \mathrm{U}\left(\eta^{4}-1,2,3,4-\mathrm{PhC} \mathrm{C}_{4} \mathrm{Ph}\right)$ (1). This new member in the family of all-carbon actinide metallacycles was fully characterized, and UV-visible electronic absorption spectroscopy suggests novelty in the electronic structure for the thorium and uranium metallacyclocumulene complexes.

\section{Experimental}

\subsection{General synthetic procedures}

Unless otherwise noted, all reactions and manipulations were performed at ambient temperature in a recirculating Vacuum Atmospheres NEXUS model inert atmosphere (Ar or $\mathrm{N}_{2}$ ) drybox equipped with a 40CFM Dual Purifier NI-Train. Glassware was dried overnight at $150{ }^{\circ} \mathrm{C}$ before use. All NMR spectra were obtained using a Bruker Avance $400 \mathrm{MHz}$ spectrometer. Chemical shifts for ${ }^{1} \mathrm{H}$ NMR spectra are reported in parts per million (ppm) were referenced to protio solvent impurities $(\delta=7.16$ for benzene- $d_{6}, 3.58$ for tetrahydrofuran- $d_{8}$ ).[25] IR spectra were obtained using a Thermo Scientific Nicolet iS5 FTIR spectrometer with a Golden Gate Diamond ATR ( $\mathrm{ZnSe}$ lenses) with a reaction anvil. UV/Vis-NIR spectra were collected with a Perkin Elmer Lambda 1050 spectrometer using $1 \mathrm{~mm}$ pathlength cuvettes; two sample concentrations were measured to optimize absorbance between $0.1-10 \mathrm{mM}$ in the NIR and UV/Vis regions. Melting points were measured with a Barnstead Thermolyne MEL-TEMP ${ }^{\circledR}$ Capillary Melting Point Apparatus using capillary tubes flame-sealed under nitrogen; values are uncorrected. Elemental analyses were performed by Atlantic Microlab, Inc. (Atlanta, GA). All samples for elemental analyses were dried under reduced pressure for at least $12 \mathrm{~h}$ before analysis to ensure the complete removal of solvent.

\subsection{Materials}

Unless otherwise noted, reagents were purchased from commercial suppliers and were used without further purification. Benzene- $d_{6}$ and tetrahydrofuran- $d_{8}$ (Cambridge Isotope Laboratories) were desiccated by storage over activated $3 \AA$ molecular sieves for at least 48 $\mathrm{h}$ prior to use. All solvents (Aldrich) were purchased anhydrous and were dried over KH for at least $24 \mathrm{~h}$, passed through a column of activated alumina, and were stored over activated $3 \AA$ molecular sieves prior to use. $\left(\mathrm{C}_{5} \mathrm{Me}_{5}\right)_{2} \mathrm{UCl}_{2},[10] \quad\left(\mathrm{C}_{5} \mathrm{Me}_{5}\right)_{2} \mathrm{UMe}_{2},[12] \quad\left[\left(\mathrm{C}_{5} \mathrm{Me}_{5}\right)_{2} \mathrm{U}(\mu-\right.$ $\mathrm{H})(\mathrm{H})]_{2},[12] \quad\left[\left(\mathrm{C}_{5} \mathrm{Me}_{5}\right)_{2} \mathrm{U}(\mathrm{H})\right]_{\mathrm{x}},[13]$ and $\mathrm{KC}_{8}$ [26] were prepared according to previous literature reports.

Caution: Depleted uranium (primary isotope ${ }^{238} U$ ) is a weak $\alpha$-emitter (4.197 MeV) with a half life of $4.47 \times 10^{9}$ 
years and natural thorium (primary isotope ${ }^{232} \mathrm{Th}$ ) is a weak $\alpha$-emitter $(4.012 \mathrm{MeV})$ with a half life of $1.41 \times 10^{10}$ years; manipulations should be carried out in a monitored fume hood or in an inert atmosphere drybox in a radiation laboratory equipped with $\alpha$-and $\beta$-counting equipment.

\subsection{Preparation of $\left(C_{5} M e_{5}\right)_{2} U\left(\eta^{4}-1,2,3,4-P h C_{4} P h\right)(\mathbf{1})$}

Method A: A 20-mL scintillation vial equipped with a stir bar was charged with $\mathrm{KC}_{8}(0.061 \mathrm{~g}, 0.451 \mathrm{mmol})$, $\left(\mathrm{C}_{5} \mathrm{Me}_{5}\right)_{2} \mathrm{UCl}_{2} \quad(0.125 \quad \mathrm{~g}, \quad 0.215 \mathrm{mmol}), \quad 1,4-$ diphenylbutadiyne $(0.044 \mathrm{~g}, 0.215 \mathrm{mmol})$, and toluene (5 $\mathrm{mL}$ ). The slurry was heated to $50{ }^{\circ} \mathrm{C}$ for $3 \mathrm{~h}$, after which it was filtered through a Celite-padded coarse-porosity fritted funnel and was extracted with toluene $(2 \times 5 \mathrm{~mL})$ until the washings ran clear. Volatiles from the resulting brown filtrate were removed under reduced pressure. The residue was extracted with pentane $(3 \times 10 \mathrm{~mL})$, and the resulting solution was filtered through a Celite-padded coarseporosity fritted funnel, and volatiles were again removed under reduced pressure to give $\left(\mathrm{C}_{5} \mathrm{Me}_{5}\right)_{2} \mathrm{U}\left(\eta^{4}-1,2,3,4\right.$ $\left.\mathrm{PhC}_{4} \mathrm{Ph}\right)(\mathbf{1})$ as a brown powder $(0.134 \mathrm{~g}, 0.189 \mathrm{mmol}$, 84\%). ${ }^{1} \mathrm{H}$ NMR (tetrahydrofuran- $d_{8}, 296 \mathrm{~K}, 400 \mathrm{MHz}$ ): $\delta=$ 6.89 (t, 2H, $J=7.3 \mathrm{~Hz}, p$-Ar), 5.42 (t, $4 \mathrm{H} J=7.6 \mathrm{~Hz}, m-$ $\mathrm{Ar}), 2.19(\mathrm{~d}, 4 \mathrm{H}, J=7.8 \mathrm{~Hz}, o-\mathrm{Ar}),-0.91\left(\mathrm{~s}, 30 \mathrm{H}, \mathrm{C}_{5} M e_{5}\right)$. ${ }^{13} \mathrm{C}\left\{{ }^{1} \mathrm{H}\right\}$ NMR (tetrahydrofuran- $d_{8}, 296 \mathrm{~K}, 125 \mathrm{MHz}$ ): $\delta=$ 188.8 (s), 188.5 (s), 156.7 (s, o-Ar), 137.0 (s, $m$-Ar), 116.8 (s, $p$-Ar), -52.1 (s, $\mathrm{C}_{5} M e_{5}$ ). Mp: $234-235^{\circ} \mathrm{C}$. Anal. Calcd. for $\mathrm{C}_{36} \mathrm{H}_{40} \mathrm{U}$ (mol. wt. 710.73): C, 60.84; H, 5.67. Found: $\mathrm{C}, 60.55 ; \mathrm{H}, 5.64$.

Method B: A Teflon-lined NMR tube was charged with $\left(\mathrm{C}_{5} \mathrm{Me}_{5}\right)_{2} \mathrm{U}\left(\eta^{2}-1,2-\mathrm{Me}_{3} \mathrm{SiC}_{2} \mathrm{SiMe}_{3}\right) \quad(0.020 \mathrm{~g}, \quad 0.0293$ mmol), 1,4-diphenylbutadiyne (0.006 g, $0.0287 \mathrm{mmol})$ and benzene- $d_{6}(0.5 \mathrm{~mL})$ at ambient temperature. After standing for 15 minutes, ${ }^{1} \mathrm{H}$ NMR revealed quantitative conversion to $\left(\mathrm{C}_{5} \mathrm{Me}_{5}\right)_{2} \mathrm{U}\left(\eta^{4}-1,2,3,4-\mathrm{PhC}_{4} \mathrm{Ph}\right)(\mathbf{1}) .{ }^{1} \mathrm{H}$ NMR (benzene- $\left.d_{6}, 296 \mathrm{~K}, 400 \mathrm{MHz}\right): \delta=6.70(\mathrm{t}, 2 \mathrm{H}, J=7.3 \mathrm{~Hz}$, $p$-Ar), 5.24 (t, 4H, $J=7.5 \mathrm{MHz}, m-\mathrm{Ar}), 2.22$ (d, 4H, $J=$ $8.2 \mathrm{MHz}, o-\mathrm{Ar}),-0.90$ (s, $30 \mathrm{H}, \mathrm{C}_{5} \mathrm{Me}_{5}$ ).

\subsection{Preparation of $\left(\mathrm{C}_{5} \mathrm{Me}_{5}\right)_{2} \mathrm{Th}\left(\eta^{4}-1,2,3,4-\mathrm{Ph} \mathrm{C}_{4} \mathrm{Ph}\right)$}

This is a modification of a literature procedure.[22] A 20-mL scintillation vial equipped with a stir bar was charged with $\mathrm{KC}_{8}(0.103 \mathrm{~g}, 0.762 \mathrm{mmol}),\left(\mathrm{C}_{5} \mathrm{Me}_{5}\right)_{2} \mathrm{ThCl}_{2}$ $(0.208 \mathrm{~g}, 0.363 \mathrm{mmol}), 1$,4-diphenylbutadiyne $(0.073 \mathrm{~g}$, $0.363 \mathrm{mmol})$, and toluene ( $5 \mathrm{~mL}$ ). The slurry was heated to $50{ }^{\circ} \mathrm{C}$ for $3 \mathrm{~h}$, after which it was filtered through a Celitepadded coarse-porosity fritted funnel and was extracted with toluene $(2 \times 3 \mathrm{~mL})$ until the washings ran clear. Volatiles from the resulting dark red filtrate were removed under reduced pressure. The residue was extracted with hexane $(3 \times 10 \mathrm{~mL})$, and the resulting solution was filtered through a Celite-padded coarse-porosity fritted funnel, and volatiles were removed under reduced pressure to $2 \mathrm{~mL}$. This solution was cooled to $-30{ }^{\circ} \mathrm{C}$ for $48 \mathrm{~h}$, which resulted in the deposition of dark red crystals identified as pure $\left(\mathrm{C}_{5} \mathrm{Me}_{5}\right)_{2} \mathrm{Th}\left(\eta^{4}-1,2,3,4-\mathrm{PhC}_{4} \mathrm{Ph}\right) \quad(0.155 \mathrm{~g}, \quad 0.269$ mmol, $74 \%) .{ }^{1} \mathrm{H}$ NMR data were consistent with literature values.[22] ${ }^{1} \mathrm{H}$ NMR (benzene- $d_{6}, 296 \mathrm{~K}, 400 \mathrm{MHz}$ ): $\delta$ $8.11(\mathrm{~d}, J=7.2 \mathrm{~Hz}, 4 \mathrm{H}), 7.39(\mathrm{t}, J=8.0 \mathrm{~Hz}, 4 \mathrm{H}), 7.15(\mathrm{~m}$, $2 \mathrm{H}), 1.82\left(\mathrm{~s}, 30 \mathrm{H}, \mathrm{C}_{5} M e_{5}\right)$.

\subsection{Synthesis of $\left(C_{5} \mathrm{Me}_{5}\right)_{2} U\left(\eta^{2}-1,2-\mathrm{Me}_{3} \mathrm{SiC}_{2} \mathrm{SiMe}_{3}\right)$}

This is a modification to a literature procedure.[27] A 20 $\mathrm{mL}$ scintillation vial equipped with a stir bar was charged with $\mathrm{KC}_{8}(0.099 \mathrm{~g}, 0.732 \mathrm{mmol}),\left(\mathrm{C}_{5} \mathrm{Me}_{5}\right)_{2} \mathrm{UCl}_{2}(0.202 \mathrm{~g}$, $0.349 \mathrm{mmol})$, bis(trimethylsilyl)acetylene $(0.119 \mathrm{~g}, 0.678$ $\mathrm{mmol})$, and toluene $(5 \mathrm{~mL})$. The reaction was allowed to stir at ambient temperature for $16 \mathrm{~h}$, resulting in a color change from dark red to green. The slurry was then heated at $50{ }^{\circ} \mathrm{C}$ for $2.5 \mathrm{~h}$, resulting in a color change from green to brown. The reaction mixture was then filtered through a Celite-padded coarse-porosity fritted funnel, which was rinsed with toluene $(5 \mathrm{~mL})$ until the washings ran clear. Volatiles were removed under reduced pressure at $50{ }^{\circ} \mathrm{C}$, and the remaining residue was dissolved in pentane $(2 \times 10$ $\mathrm{mL}$ ), which was then filtered through a coarse-porosity fritted funnel. Volatiles were removed from the filtrate under reduced pressure at ambient temperature, and once all visible liquids had been removed the temperature was increased to $50{ }^{\circ} \mathrm{C}$ to ensure the removal of all excess bis(trimethylsilyl)acetylene. This gave $\left(\mathrm{C}_{5} \mathrm{Me}_{5}\right)_{2} \mathrm{U}\left(\eta^{2}-1,2-\right.$ $\left.\mathrm{Me}_{3} \mathrm{SiC}_{2} \mathrm{SiMe}_{3}\right)$ as a dark brown powder $(0.175 \mathrm{~g}, 0.258$ mmol, $74 \%) .{ }^{1} \mathrm{H}$ NMR data were consistent with literature values.[27] ${ }^{1} \mathrm{H}$ NMR (benzene- $d_{6}, 296 \mathrm{~K}, 400 \mathrm{MHz}$ ): $\delta$ 8.24 (s, 18H, $-\mathrm{SiMe}_{3}$ ), -6.32 (s, 30H, $\mathrm{C}_{5} M e_{5}$ ).

\section{$2.5 X$-ray Crystallography}

Data for 1 were collected on a Bruker D8 Quest diffractometer, with CMOS detector in shutterless mode. The crystals were cooled to using an Oxford Cryostream liquid nitrogen cryostat. Both data collections employed graphite monochromatized $\operatorname{MoK} \alpha \quad(\lambda=0.71073 \AA)$ radiation. Hemispheres of data were collected with $\omega$ scans. Data collection, initial indexing, and cell refinement were handled with APEX II software.[28] Frame integration, including Lorentz-polarization corrections, and final cell parameter calculations were carried out with SAINT+ software.[29] The data were corrected for absorption with the SADABS program.[30] The structure was solved with direct methods and difference Fourier techniques. Non-hydrogen atoms were refined anisotropically, and hydrogen atoms were treated as idealized contributions. The two $\left(\mathrm{C}_{5} \mathrm{Me}_{5}\right)$ ligands were disordered across a mirror plane, and each refined at one- 
half occupancy. The phenyl groups were also disordered, and refined in two positions with site-occupancy-factors tied to 1.0. Structure solution and refinement were performed with SHELXTL.[31] Additional details of data collection and structure refinement are listed in Table 1.

\section{Results and discussion}

3.1 Synthesis and structural characterization of the uranium metallacyclocumulene complex $\left(\mathrm{C}_{5} \mathrm{Me}_{5}\right)_{2} U\left(\eta^{4}-\right.$ 1,2,3,4-PhC $\left.\mathrm{C}_{4} \mathrm{Ph}\right)$

As shown in Eq. (1), reaction of $\left(\mathrm{C}_{5} \mathrm{Me}_{5}\right)_{2} \mathrm{UCl}_{2}$ with 2.1 equiv. of $\mathrm{KC}_{8}$ and 1 equiv. of 1,4-diphenylbutadiyne in toluene at $50{ }^{\circ} \mathrm{C}$ for $3 \mathrm{~h}$ gave the five-membered uranacyclocumulene

(uranacyclopenta-2,3,4-triene)
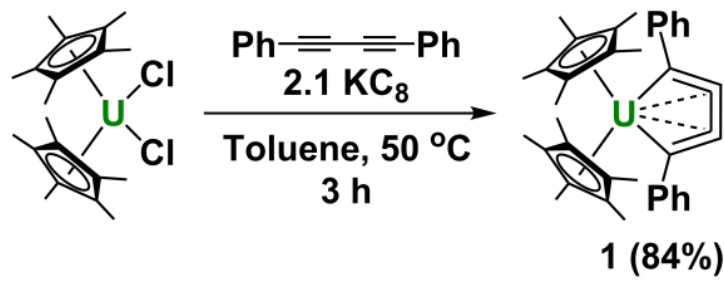

$\left(\mathrm{C}_{5} \mathrm{Me}_{5}\right)_{2} \mathrm{U}\left(\eta^{4}-1,2,3,4-\mathrm{PhC} \mathrm{C}_{4} \mathrm{Ph}\right)(\mathbf{1})$.

Separation of the insoluble salts and graphite from the reaction mixture was accomplished by filtration through Celite. Following workup, the uranium metallacyclocumulene complex (16) was obtained as a dark brown powder in $84 \%$ isolated yield.

Complex 1 was fully characterized by a combination of ${ }^{1} \mathrm{H}$ and ${ }^{13} \mathrm{C}\left\{{ }^{1} \mathrm{H}\right\} \quad$ NMR, IR and UV-visible-near-IR absorption spectroscopy, elemental analysis, and singlecrystal X-ray diffraction. At ambient temperature, the ${ }^{1} \mathrm{H}$ NMR spectrum of $\mathbf{1}$ in THF- $d_{8}$ is characterized by sharp and paramagnetically shifted resonances signals at $\delta=6.89(2 \mathrm{H}, p-\mathrm{H}), 5.42(4 \mathrm{H}, m-\mathrm{H}), 2.19(4 \mathrm{H}, o-\mathrm{H})$, and $-0.91\left(30 \mathrm{H}, \mathrm{C}_{5} \mathrm{Me}_{5}\right)$. Interestingly, unlike most uranium complexes, the ${ }^{13} \mathrm{C}\left\{{ }^{1} \mathrm{H}\right\}$ NMR spectrum for $\mathbf{1}$ can be obtained, but only five out of the expected resonances are observed.[32]

The IR spectrum for $\left(\mathrm{C}_{5} \mathrm{Me}_{5}\right)_{2} \mathrm{U}\left(\eta^{4}-1,2,3,4-\mathrm{PhC}_{4} \mathrm{Ph}\right)$ (1) shows a strong absorption band at $1590 \mathrm{~cm}^{-1}$, which corresponds to the $\mathrm{C}_{\alpha}-\mathrm{C}_{\beta}$ stretching mode of the butatriene unit,[22, 27, 33] and compares well with the data obtained for the structurally similar metallcyclocumulene complexes $\left(\mathrm{C}_{5} \mathrm{Me}_{5}\right)_{2} \mathrm{Th}\left(\eta^{4}-1,2,3,4-\mathrm{PhC}_{4} \mathrm{Ph}\right)\left(1600 \mathrm{~cm}^{-1}\right)$, $\left(\mathrm{C}_{5} \mathrm{Me}_{5}\right)_{2} \mathrm{Th}\left(\eta^{4}-1,2,3,4-\mathrm{Me}_{3} \mathrm{SiC}_{4} \mathrm{SiMe}_{3}\right)\left(1582 \mathrm{~cm}^{-1}\right)$, and $\left(\mathrm{C}_{5} \mathrm{Me}_{5}\right)_{2} \mathrm{U}\left(\eta^{4}-1,2,3,4-\mathrm{Me}_{3} \mathrm{SiC}_{4} \mathrm{SiMe}_{3}\right)\left(1572 \mathrm{~cm}^{-1}\right)$.

The NIR spectrum of $\mathbf{1}$ displays a series of narrow bands of relatively low-intensity $\left(\varepsilon<200 \mathrm{~cm}^{-1} \mathrm{M}^{-1}\right)$ attributable to intraconfiguration $\mathrm{f}-\mathrm{f}$ transitions consistent with previously characterized uranium(IV) bent metallocene species and allows for unambiguous assignment of the oxidation state for $\mathbf{1}$ (Figure 1).[34] Notably, the UVvisible region of this spectrum between $35,000 \mathrm{~cm}^{-1}$ and $16,000 \mathrm{~cm}^{-1}$ displays two main bands each of which appears to have additional structure (vide infra). This additional, finer structure is likely attributable to resolution of vibronic bands and is seen, for example, in a number of $\mathrm{UO}_{2}{ }^{2+}$ complexes,[35] but is rare for uranium(IV) metallocenes.[34]

As noted above, we[12, 13] and others[14, 16-18] have shown that the uranium(IV) $\left[\left(\mathrm{C}_{5} \mathrm{Me}_{5}\right)_{2} \mathrm{U}(\mu-\mathrm{H})(\mathrm{H})\right]_{2}$ and uranium(III) $\left[\left(\mathrm{C}_{5} \mathrm{Me}_{5}\right)_{2} \mathrm{U}(\mathrm{H})\right]_{\mathrm{x}}$ hydride complexes are effective low-valent equivalents for the synthesis of uranium metallacyclopentadiene complexes; however, we observed no reactivity between either of the uranium hydride complexes with 1,4-diphenylbutadiyne, even under forcing conditions.

Interestingly, the uranacyclocumulene $\mathbf{1}$ can be synthesized quantitatively by reaction of $\left(\mathrm{C}_{5} \mathrm{Me}_{5}\right)_{2} \mathrm{U}\left(\eta^{2}-\right.$ 1,2- $\left.\mathrm{Me}_{3} \mathrm{SiC}_{2} \mathrm{SiMe}_{3}\right)$ with 1,4-diphenylbutadiyne in benzene- $d_{6}$ at ambient temperature as shown in Eq. (2).

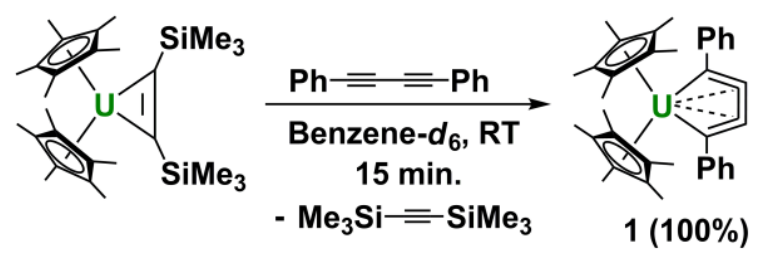

This is an elegant and effective route for obtaining uranium metallacyclocumulene complexes, and also works with 1,4-bis(trimethylsilyl)butadiyne to prepare $\left(\mathrm{C}_{5} \mathrm{Me}_{5}\right)_{2} \mathrm{U}\left(\eta^{4}-1,2,3,4-\mathrm{Me}_{3} \mathrm{SiC}_{4} \mathrm{SiMe}_{3}\right)$.[27] It is important to note, as reported by Rosenthal and co-workers, this chemistry is not observed for the analogous titanium and zirconium metallacyclopropene complexes, $\left(\mathrm{C}_{5} \mathrm{Me}_{5}\right)_{2} \mathrm{M}\left(\eta^{2}-1,2-\mathrm{Me}_{3} \mathrm{SiC}_{2} \mathrm{SiMe}_{3}\right)(\mathrm{M}=\mathrm{Ti}, \mathrm{Zr})$, which did not react with $\mathrm{Ph}-\mathrm{C} \equiv \mathrm{C}-\mathrm{C} \equiv \mathrm{C}-\mathrm{Ph}$ or $\mathrm{Me}_{3} \mathrm{Si}-\mathrm{C} \equiv \mathrm{C}-\mathrm{C} \equiv \mathrm{C}$ $\mathrm{SiMe}_{3}$.[36] Walter and coworkers also noted that the related thorium system $\left(\mathrm{C}_{5} \mathrm{Me}_{5}\right)_{2} \mathrm{Th}\left(\eta^{4}-1,2,3,4-\mathrm{PhC} \mathrm{C}_{4} \mathrm{Ph}\right)$ did not react with 1,4-butadiynes to form thorium metallacyclocumulene complexes.[37] 

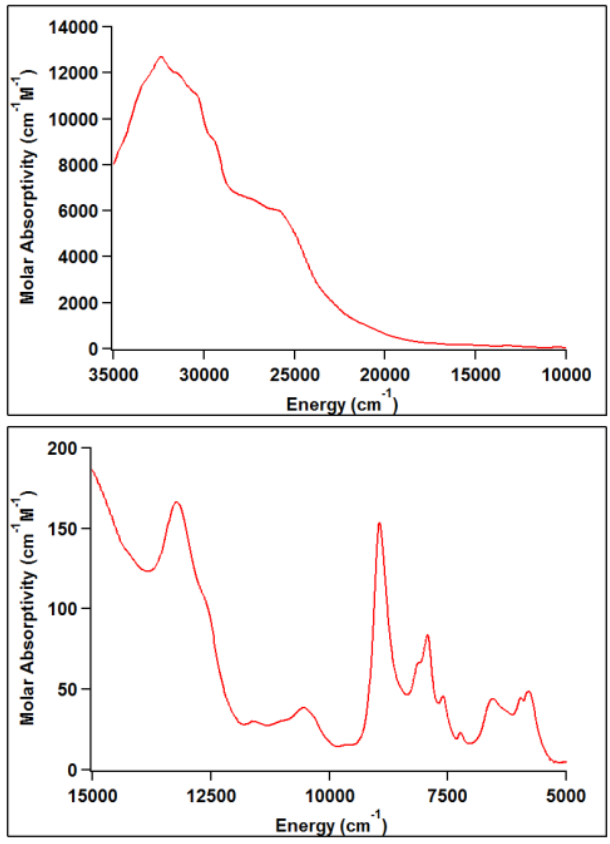

Figure 1. Room temperature UV-visible-NIR electronic absorption spectral data for $\left(\mathrm{C}_{5} \mathrm{Me}_{5}\right)_{2} \mathrm{U}\left(\eta^{4}-1,2,3,4-\mathrm{PhC}{ }_{4} \mathrm{Ph}\right)(\mathbf{1})$ in toluene.

Single crystals of compound $\mathbf{1}$ were obtained from a concentrated $n$-pentane solution at $-30{ }^{\circ} \mathrm{C}$. Figure 2 shows the molecular structure of complex $\mathbf{1}$, which reveals a typical bent metallocene framework with a pseudotetrahedral coordination environment around the uranium metal center. Within the metallocene wedge lies the cumulene ligand in a planar arrangement. The $\mathrm{C}_{1}-\mathrm{C}_{2}$ $\left(\mathrm{C}_{\alpha}-\mathrm{C}_{\beta}\right)$ and $\mathrm{C}_{2}-\mathrm{C}_{2^{\prime}}\left(\mathrm{C}_{\beta}-\mathrm{C}_{\beta^{\prime}}\right)$ bond distances of $\mathbf{1}$ are 1.308(3) $\AA$ and 1.314(3) $\AA$, respectively, and indicate that the three $\mathrm{C}-\mathrm{C}$ bonds possess double bond character. These data are consistent a $\eta^{4}-1,2,3,4$-butatrienediyl moiety bound to the uranium metal center and compare favorably to the known derivatives $\left(\mathrm{C}_{5} \mathrm{Me}_{5}\right)_{2} \mathrm{U}\left(\eta^{4}-1,2,3,4-\right.$ $\left.\mathrm{Me}_{3} \mathrm{SiC}_{4} \mathrm{SiMe}_{3}\right)\left(\mathrm{C}_{\alpha}-\mathrm{C}_{\beta}=1.299(7), 1.295(7) \AA ; \mathrm{C}_{\beta}-\mathrm{C}_{\beta^{\prime}}=\right.$ 1.314(7) ̊),[27] $\left(\mathrm{C}_{5} \mathrm{Me}_{5}\right)_{2} \mathrm{Th}\left(\eta^{4}-1,2,3,4-\mathrm{PhC}_{4} \mathrm{Ph}\right)(7)\left(\mathrm{C}_{\alpha}-\right.$ $\left.\mathrm{C}_{\beta}=1.321(1), 1.284(1) \AA ; \mathrm{C}_{\beta}-\mathrm{C}_{\beta^{\prime}}=1.341(1) \AA\right),[27]$ and $\left(\mathrm{C}_{5} \mathrm{Me}_{5}\right)_{2} \mathrm{Zr}\left(\eta^{4}-1,2,3,4-\mathrm{PhC}_{4} \mathrm{Ph}\right) \quad\left(\mathrm{C}_{\alpha}-\mathrm{C}_{\beta}=1.296(4)\right.$, 1.305(5) $\left.\AA ; \mathrm{C}_{\beta}-\mathrm{C}_{\beta^{\prime}}=1.327(4) \AA\right)$.[36] The four carbon atoms of the ring $\left(\mathrm{C}_{\alpha}, \mathrm{C}_{\alpha^{\prime}}, \mathrm{C}_{\beta}\right.$ and $\left.\mathrm{C}_{\beta^{\prime}}\right)$ have $\mathrm{p}$ orbitals perpendicular to the plane of the metallacyclocumulene unit. The sp-hybridized internal $\mathrm{C}_{\beta}$ and $\mathrm{C}_{\beta^{\prime}}$ atoms possess additional $\mathrm{p}$ orbitals in the metallacyclocumulene plane. Employing these orbitals, the central $\mathrm{C}=\mathrm{C}$ double bond is coordinated to the uranium metal center, resulting in an elongated $\mathrm{C}_{\beta}-\mathrm{C}_{\beta^{\prime}}$. In agreement with this bonding description, the $\mathrm{U}-\mathrm{C}_{\beta}$ distances $\left(\mathrm{U}_{1}-\mathrm{C}_{2}=\mathrm{U}_{1}-\mathrm{C}_{2^{\prime}}=\right.$ 2.439(2) $\AA$ ) are shorter than the $\mathrm{U}-\mathrm{C}_{\alpha}$ distances $\left(\mathrm{U}_{1}-\mathrm{C}_{1}=\right.$ $\mathrm{U}_{1}-\mathrm{C}_{1^{\prime}}=2.462(2) \AA$ ). These metrical parameters compare well with those reported for the other uranium metallacyclocumulene complex $9\left(\mathrm{U}_{1}-\mathrm{C}_{\alpha}=2.487(5)\right.$, 2.514(5) $\left.\AA ; \quad \mathrm{U}_{1}-\mathrm{C}_{\beta}=2.435(5), \quad 2.434(5) \quad \AA\right) .[27]$ Additionally, the $\mathrm{C}_{1}-\mathrm{C}_{2}-\mathrm{C}_{2^{\prime}}=\mathrm{C}_{1^{\prime}}-\mathrm{C}_{2^{\prime}}-\mathrm{C}_{2}=148.1(2)^{\circ}$ is similar to that reported for $9\left(\mathrm{C}_{\alpha}-\mathrm{C}_{\beta}-\mathrm{C}_{\beta^{\prime}}=151.3(5)^{\circ}\right.$ and $\left.\mathrm{C}_{\alpha}, \mathrm{C}_{\beta}, \mathrm{C}_{\beta}=152.6(5)^{\circ}\right)$.[27]

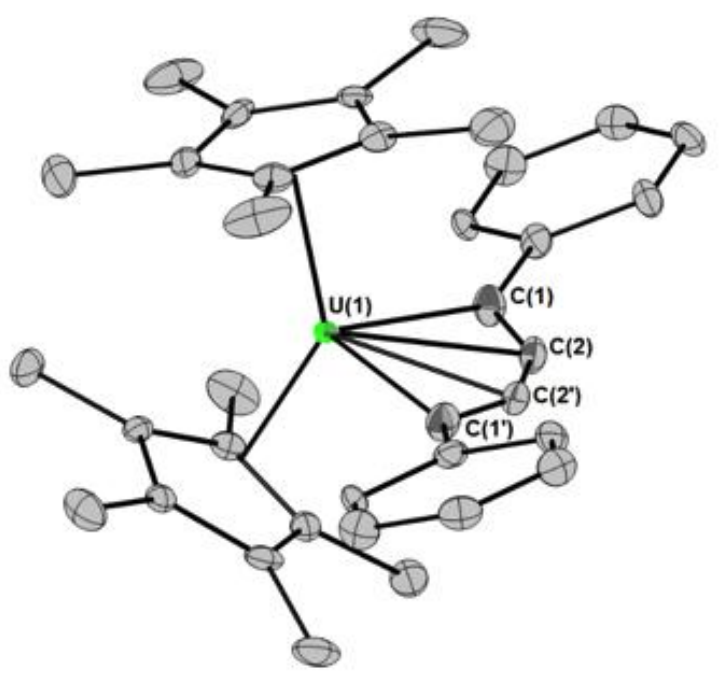

Figure 2. Molecular structure of $\left(\mathrm{C}_{5} \mathrm{Me}_{5}\right)_{2} \mathrm{U}\left(\eta^{4}-1,2,3,4-\mathrm{PhC}{ }_{4} \mathrm{Ph}\right)(\mathbf{1})$ with thermal ellipsoids projected at the $50 \%$ probability level. Hydrogen atoms have been omitted for clarity. Selected bond

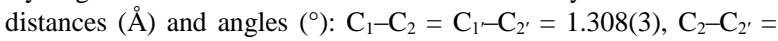
1.314(3), $\mathrm{U}_{1}-\mathrm{C}_{1}=\mathrm{U}_{1}-\mathrm{C}_{1^{\prime}}=2.462(2), \mathrm{U}_{1}-\mathrm{C}_{2}=\mathrm{U}_{1}-\mathrm{C}_{2^{\prime}}=2.439(2)$, U$\mathrm{Cp}_{\text {cent }}=2.458(2), 2.463(4), \mathrm{C}_{1}-\mathrm{C}_{2}-\mathrm{C}_{2^{\prime}}=\mathrm{C}_{1},-\mathrm{C}_{2}-\mathrm{C}_{2}=148.1(2), \mathrm{C}_{1}-$ $\mathrm{U}_{1}-\mathrm{C}_{1^{\prime}}=92.9, \mathrm{Cp}_{\text {cent }}-\mathrm{U}-\mathrm{Cp}_{\text {cent }}=138.1(2)$. 
Table 1. Summary of X-ray crystallographic data for $\left(\mathrm{C}_{5} \mathrm{Me}_{5}\right)_{2} \mathrm{U}\left(\eta^{4}-1,2,3,4-\mathrm{PhC}_{4} \mathrm{Ph}\right)(\mathbf{1})$.

\begin{tabular}{ll}
\hline Empirical formula & $\mathrm{C}_{36} \mathrm{H}_{40} \mathrm{U}$ \\
Formula weight & 710.73 \\
Temperature $(\mathrm{K})$ & 140 \\
Wavelength $(\AA)$ & 0.71073 \\
Crystal system & Orthorhombic \\
Space group & $C m c a$ \\
Unit Cell Dimensions & \\
$a(\AA)$ & $15.383(1)$ \\
$b(\AA)$ & $14.442(1)$ \\
$c(\AA)$ & $26.006(2)$ \\
Volume $\left(\AA^{3}\right)$ & $5777.5(7)$ \\
$\mathrm{Z}$ & 8 \\
$D_{\text {calc }}\left(\mathrm{g} / \mathrm{cm}^{3}\right)$ & 1.634 \\
Crystal size $\left(\mathrm{mm}{ }^{3}\right)$ & $0.210 \times 0.280 \times 0.384$ \\
$\mu\left(\right.$ MoK $\left.\alpha, \mathrm{mm}^{-1}\right)$ & 5.641 \\
$F(000)$ & 2784 \\
$\Theta$ Range $\left({ }^{\circ}\right)$ & $2.49-35.39$ \\
$2 \theta_{\text {max }}\left({ }^{\circ}\right)$ & 70.8 \\
Index Ranges & $-23 \leq h \leq 24$ \\
& $-23 \leq k \leq 23$ \\
& $-41 \leq l \leq 40$ \\
Reflections collected/unique & $6522 / 4829$ \\
Data/parameters & $4829 / 300$ \\
Goodness-of-fit on $\mathrm{F}^{2}$ & 1.088 \\
Final $R$ Indices $[I>2 \sigma(I)]$ & $R_{1}=0.0325, w R_{2}=0.0507$ \\
$R$ Indices $($ all data) & $R_{1}=0.0637, w R_{2}=0.0558$ \\
Largest difference in peak & 1.149 \\
and hole $\left(\mathrm{e} / \AA^{3}\right)$ & -1.521 \\
\hline
\end{tabular}

\subsection{Optical characterization of the metallacyclocumulene complexes $\left(C_{5} M e_{5}\right)_{2} A n\left(\eta^{4}-1,2,3,4-P h C_{4} P h\right)(A n=T h, U)$}

The characteristic features in the electronic spectra of $f-$ elements are the $\mathrm{f}-\mathrm{f}$ transitions that take place between the spin-orbit induced and crystal-field split energy levels derived from the f-electron states.[38] However, chargetransfer electronic excitations that promote electrons to/from the metal center and the ligand are also an essential ingredient in these systems of redox active metals and ligands. For uranium(IV) organometallic complexes, these metal (f-orbital)-to-ligand charge transfer (MLCT) transitions are typically observed as weak, lower energy features in the visible region (e.g., the bands at $\sim 16,500$ $\mathrm{cm}^{-1}$ for $\left(\mathrm{C}_{5} \mathrm{Me}_{5}\right)_{2} \mathrm{U}\left(-\mathrm{N}=\mathrm{CPh}_{2}\right)_{2}$; Figure 3, top panel). Such transitions are not possible for analogous thorium(IV) organometallic complexes because of the lack of valence $\mathrm{f}-$ or $\mathrm{d}$-electrons. Our ongoing studies of electronic spectroscopy in organoactinide complexes have provided an evolving picture of the importance of electronic transition intensities in qualitatively assessing metal-ligand covalency and electronic coupling between excited states of differing orbital parentage.[39, 40] In particular, we have learned that transition intensities in the $f-f$ bands of many uranium complexes are dramatically enhanced from covalent bonding interactions and from coupling of the other low-lying electronic excitations (e.g., MLCT excited states) to the $\mathrm{f}-\mathrm{f}$ transitions to engender dipole-allowed character.[41-43] For example, the molar extinction coefficients for $\mathrm{f}-\mathrm{f}$ bands in uranium(IV) organometallic complexes have been found to range from $<<10 \mathrm{M}^{-1} \mathrm{~cm}^{-1}$ in non-covalent metal-ligand systems like $\left(\mathrm{C}_{5} \mathrm{Me}_{5}\right)_{2} \mathrm{UCl}_{2}$ to $\sim 500 \mathrm{M}^{-1} \mathrm{~cm}^{-1}$ in covalent metal-ligand systems like ketimide complexes such as $\left(\mathrm{C}_{5} \mathrm{Me}_{5}\right)_{2} \mathrm{U}\left(-\mathrm{N}=\mathrm{CPh}_{2}\right)_{2}$. [34, 44-47]

The electronic spectral behavior of the metallacyclocumulene systems $\left(\mathrm{C}_{5} \mathrm{Me}_{5}\right)_{2} \mathrm{An}\left(\eta^{4}-1,2,3,4-\right.$ $\left.\mathrm{PhC}_{4} \mathrm{Ph}\right)(\mathrm{An}=\mathrm{Th}, \mathrm{U})$ reported here diverges from that observed for most other Th and U organoactinide systems we have investigated in two ways. First, the uranium complex (1) does not appear to possess the very low energy visible electronic bands associated with MLCT transitions derived from occupied f-orbitals (Figure 3, bottom panel). Despite the absence of this common indication of metal-ligand orbital mixing, the intensities in the NIR spectral bands for $1\left(\sim 50-150 \mathrm{M}^{-1} \mathrm{~cm}^{-1}\right.$; Figure 1, bottom panel) do still clearly reflect enhanced covalent metal-ligand bonding. Second, the lowest energy visible absorption bands in this system are seen for the thorium complex ( 17,500-20,000 $\mathrm{cm}^{-1}$; Figure 3, bottom panel), not the uranium complex. In most cases, there is a strong correlation in the electronic absorption features between homologous $\left(\mathrm{C}_{5} \mathrm{Me}_{5}\right)_{2} \mathrm{An}\left(-\mathrm{N}=\mathrm{CPh}_{2}\right)_{2}(\mathrm{An}=\mathrm{Th}$, U; Figure 3 , top panel) throughout the visible and ultraviolet spectral regions because these are the spectral regions for electronic transitions involving molecular orbitals that are comparable for both metal complexes. For these metallacyclocumulenes all other structural and spectroscopic data suggest that the ligand-based orbital descriptions are comparable for both complexes, yet the correlation in the UV-visible region is lacking. This new lower energy visible spectral feature for the thorium complex seems most likely attributable to a transition involving unoccupied Th-based orbitals (e.g., a ligand-tometal charge transfer band), but the very low observed energy for this transition differs from any behavior we have observed previously for thorium vs. uranium metallocene complexes, suggesting that the metal-ligand bonding interactions between the thorium and uranium metallacyclocumulene complexes are fundamentally different and potentially engaging metal $\mathrm{f}$ - and d-orbitals to a very different extent. Theoretical efforts are underway to understand this observed difference in spectral behavior and hence molecular orbital parentage and relative energetic ordering.

\section{Conclusions}


In conclusion, we have synthesized the new uranium metallacyclocumulene $\left(\mathrm{C}_{5} \mathrm{Me}_{5}\right)_{2} \mathrm{U}\left(\eta^{4}-1,2,3,4-\mathrm{PhC}_{4} \mathrm{Ph}\right)$ (1) by two methods involving low-valent uranium equivalents. Both the $\mathrm{KC}_{8}$ reduction of like $\left(\mathrm{C}_{5} \mathrm{Me}_{5}\right)_{2} \mathrm{UCl}_{2}$ in the presence of 1,4-diphenylbutadiyne and the ligand exchange between $\left(\mathrm{C}_{5} \mathrm{Me}_{5}\right)_{2} \mathrm{U}\left(\eta^{2}-1,2-\mathrm{Me}_{3} \mathrm{SiC}_{2} \mathrm{SiMe}_{3}\right)$ and 1,4-diphenylbutadiyne gave pure $\mathbf{1}$ upon workup. We observed interesting differences in the ultraviolet and visible spectral region for the homologous metallacyclocumulene complexes, $\left(\mathrm{C}_{5} \mathrm{Me}_{5}\right)_{2} \mathrm{An}\left(\eta^{4}-1,2,3,4-\right.$ $\left.\mathrm{PhC}_{4} \mathrm{Ph}\right)(\mathrm{An}=\mathrm{Th}, \mathrm{U})$, which suggest that the metal-ligand bonding interactions between the thorium and uranium metallacyclocumulene complexes are fundamentally different, potentially engaging the metal $\mathrm{f}$ - and d-orbitals to a different extent. We are currently investigating the unusual spectroscopic properties of actinide metallacyclocumulenes as well as other actinide metallacycles, and our studies will be reported in due course.

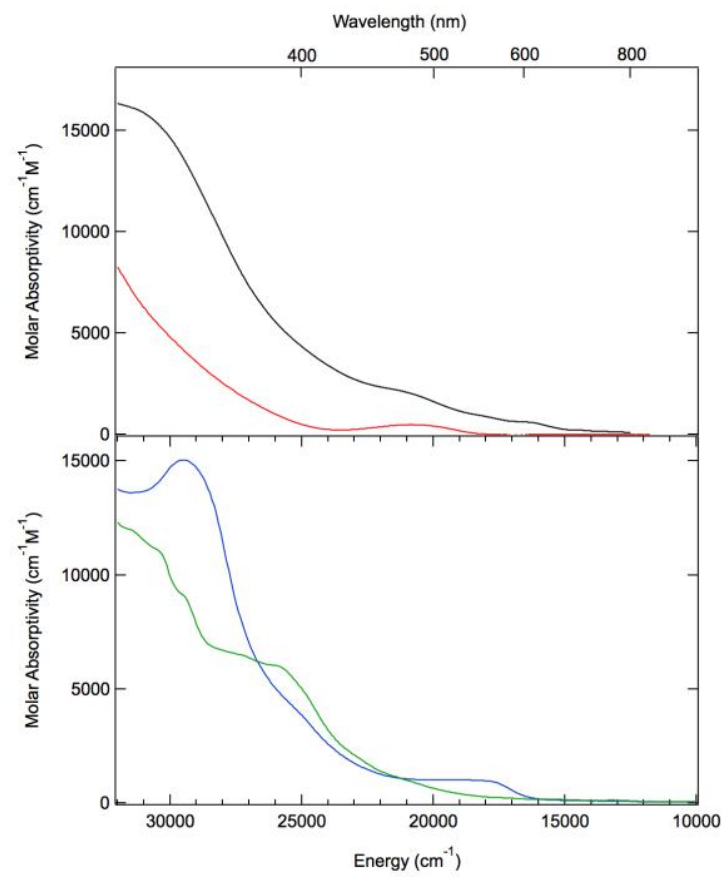

Figure 3. UV-visible electronic spectral data illustrating the strong correlation of spectral features in $\left(\mathrm{C}_{5} \mathrm{Me}_{5}\right)_{2} \mathrm{An}\left(-\mathrm{N}=\mathrm{CPh}_{2}\right)_{2}(\mathrm{An}=\mathrm{Th}$ (red), $\mathrm{U}$ (black) complexes in contrast to recent results for $\left(\mathrm{C}_{5} \mathrm{Me}_{5}\right)_{2} \mathrm{An}\left(\eta^{4}-1,2,3,4-\mathrm{PhC}_{4} \mathrm{Ph}\right) \quad(\mathrm{An}=\mathrm{Th}$ (blue), U (1, green $)$ complexes for which the correlation breaks down.

\section{Acknowledgements}

For financial support of this work, we acknowledge the U.S. Department of Energy through the Office of Workforce Development for Teachers and Scientists, Office of Science Graduate Student Research (SCGSR) program (GRA Fellowship to J.K.P.), the LANL LDRD
Program, the LANL G. T. Seaborg Institute for Transactinium Science (Postdoctoral Fellowship to K.A.E.), and the Office of Basic Energy Sciences, Heavy Element Chemistry program (J.L.K., B.L.S., materials \& supplies). We also acknowledge the U.S. National Science Foundation (grant CHE-1265608 and CHE-1565658 to R.W.). The SCGSR program is administered by the Oak Ridge Institute for Science and Education for the DOE (contract DE-AC05-06OR23100). Los Alamos National Laboratory is operated by Los Alamos National Security, LLC, for the National Nuclear Security Administration of U.S. Department of Energy (contract DE-AC5206NA25396).

\section{Appendix A. Supplementary data}

Relevant spectra for $\left(\mathrm{C}_{5} \mathrm{Me}_{5}\right)_{2} \mathrm{U}\left(\eta^{4}-1,2,3,4-\mathrm{PhC}_{4} \mathrm{Ph}\right)(\mathbf{1})$ can be found in the attached supplementary material. Crystallographic data were deposited with the Cambridge Crystallographic Data Centre, CCDC 1501132. These data can be obtained free of charge via www.ccdc.cam.ac.uk/data_request/cif.

\section{References}

[1] R.H. Crabtree, The Organometallic Chemistry of the Transition Metals, 4th ed ed., John Wiley \& Sons, Hoboken, NJ, 2005.

[2] Y. Chauvin, Angew. Chem., Int. Ed. 45(23) (2006) 3740-3747.

[3] R.H. Grubbs, Angew. Chem., Int. Ed. 45(23) (2006) 3760-3765.

[4] R.R. Schrock, Angew. Chem., Int. Ed. 45(23) (2006) 3748-3759.

[5] G. He, L. Kang, W. Torres Delgado, O. Shynkaruk, M.J. Ferguson, R. McDonald, E. Rivard, J. Am. Chem. Soc. 135(14) (2013) 5360-5363.

[6] G. He, W. Torres Delgado, D.J. Schatz, C. Merten, A. Mohammadpour, L. Mayr, M.J. Ferguson, R. McDonald, A. Brown, K. Shankar, E. Rivard, Angew. Chem., Int. Ed. 53(18) (2014) 4587-4591.

[7] G. He, B.D. Wiltshire, P. Choi, A. Savin, S. Sun, A. Mohammadpour, M.J. Ferguson, R. McDonald, S. Farsinezhad, A. Brown, K. Shankar, E. Rivard, Chem. Commun. (Cambridge, U. K.) 51(25) (2015) 5444-5447.

[8] X. Yan, C. Xi, Acc. Chem. Res. 48(4) (2015) 935-946.

[9] P.J. Fagan, J.M. Manriquez, T.J. Marks, C.S. Day, S.H. Vollmer, V.W. Day, Organometallics 1(1) (1982) 170-180. [10] P.J. Fagan, J.M. Manriquez, E.A. Maatta, A.M. Seyam, T.J. Marks, J. Am. Chem. Soc. 103(22) (1981) 6650-6667.

[11] W.J. Evans, S.A. Kozimor, J.W. Ziller, Chem. Commun. (37) (2005) 4681-4683.

[12] J.K. Pagano, J.M. Dorhout, R. Waterman, K.R. Czerwinski, J.L. Kiplinger, Chem. Commun. 51(98) (2015) 17379-17381. 
[13] J.K. Pagano, J.M. Dorhout, K.R. Czerwinski, D.E. Morris, B.L. Scott, R. Waterman, J.L. Kiplinger, Organometallics 35(5) (2016) 617-620.

[14] W.J. Evans, K.A. Miller, S.A. Kozimor, J.W. Ziller, A.G. DiPasquale, A.L. Rheingold, Organometallics 26(14) (2007) 3568-3576.

[15] W.J. Evans, K.A. Miller, J.W. Ziller, A.G. DiPasquale, K.J. Heroux, A.L. Rheingold, Organometallics 26(17) (2007) 4287-4293.

[16] W.J. Evans, E. Montalvo, S.A. Kozimor, K.A. Miller, J. Am. Chem. Soc. 130(37) (2008) 12258-12259.

[17] D.J. Grant, T.J. Stewart, R. Bau, K.A. Miller, S.A. Mason, M. Gutmann, G.J. McIntyre, L. Gagliardi, W.J. Evans, Inorg. Chem. 51(6) (2012) 3613-3624.

[18] N.A. Siladke, C.L. Webster, J.R. Walensky, M.K. Takase, J.W. Ziller, D.J. Grant, L. Gagliardi, W.J. Evans, Organometallics 32(21) (2013) 6522-6531.

[19] B. Fang, G. Hou, G. Zi, D.-C. Fang, M.D. Walter, Dalton Trans. 44(17) (2015) 7927-7934.

[20] B. Fang, G. Hou, G. Zi, D.-C. Fang, M.D. Walter, Dalton Trans. 44(17) (2015) 7927-7934.

[21] B. Fang, W. Ren, G. Hou, G. Zi, D.-C. Fang, L. Maron, M.D. Walter, J. Am. Chem. Soc. 136(49) (2014) 17249-17261.

[22] B. Fang, L. Zhang, G. Hou, G. Zi, D.-C. Fang, M.D. Walter, Organometallics 34(23) (2015) 5669-5681.

[23] B. Fang, L. Zhang, G. Hou, G. Zi, D.-C. Fang, M.D. Walter, Chem. Sci. 6(8) (2015) 4897-4906.

[24] B. Kosog, C.E. Kefalidis, F.W. Heinemann, L. Maron, K. Meyer, J. Am. Chem. Soc. 134(30) (2012) 12792-12797.

[25] G.R. Fulmer, A.J.M. Miller, N.H. Sherden, H.E. Gottlieb, A. Nudelman, B.M. Stoltz, J.E. Bercaw, K.I. Goldberg, Organometallics 29(9) (2010) 2176-2179.

[26] M.A. Schwindt, T. Lejon, L.S. Hegedus, Organometallics 9(10) (1990) 2814-2819.

[27] L. Zhang, G. Hou, G. Zi, W. Ding, M.D. Walter, J. Am. Chem. Soc. 138(15) (2016) 5130-5142.

[28] APEX2, v. 2014.7-1; Bruker AXS: Madison, Wi, 2014.

[29] SAINT, v. 8.34A; Bruker AXS: Madison, WI, 2013. [30] SADABS, v. 2014/3; Bruker AXS: Madison, WI, 2013.

[31] SHELXTL, v. 6.14; Bruker AXS: Madison, WI, 2000.

[32] See supporting information for details

[33] P. Yang, E. Zhou, B. Fang, G. Hou, G. Zi, M.D. Walter, Organometallics 35(12) (2016) 2129-2139.
[34] D.E. Morris, R.E. Da Re, K.C. Jantunen, I. CastroRodriguez, J.L. Kiplinger, Organometallics 23(22) (2004) 5142-5153.

[35] R.G. Denning, Electronic structure and bonding in actinyl ions, Complexes, Clusters and Crystal Chemistry, Springer Berlin Heidelberg, Berlin, Heidelberg, 1992, pp. 215-276.

[36] P.-M. Pellny, F.G. Kirchbauer, V.V. Burlakov, W. Baumann, A. Spannenberg, U. Rosenthal, J. Am. Chem. Soc. 121(36) (1999) 8313-8323.

[37] B. Fang, W. Ren, G. Hou, G. Zi, D.-C. Fang, L. Maron, M.D. Walter, J. Am. Chem. Soc. 136(49) (2014) 17249-17261.

[38] D.G. Karraker, J.A. Stone, E.R. Jones, N. Edelstein, J. Am. Chem. Soc. 92(16) (1970) 4841-4845.

[39] H. Yasuoka, G. Koutroulakis, H. Chudo, S. Richmond, D.K. Veirs, A.I. Smith, E.D. Bauer, J.D. Thompson, G.D. Jarvinen, D.L. Clark, Science 336(6083) (2012) 901.

[40] D.C. Sonnenberger, J. Gaudiello, Journal of the Less Common Metals 126 (1986) 411-414.

[41] S.A. Kozimor, P. Yang, E.R. Batista, K.S. Boland, C.J. Burns, C.N. Christensen, D.L. Clark, S.D. Conradson, P.J. Hay, J.S. Lezama, R.L. Martin, D.E. Schwarz, M.P. Wilkerson, L.E. Wolfsberg, Inorg. Chem. 47(12) (2008) 5365-5371.

[42] S.A. Kozimor, P. Yang, E.R. Batista, K.S. Boland, C.J. Burns, D.L. Clark, S.D. Conradson, R.L. Martin, M.P. Wilkerson, L.E. Wolfsberg, J. Am. Chem. Soc. 131(34) (2009) 12125-12136.

[43] S.G. Minasian, J.M. Keith, E.R. Batista, K.S. Boland, S.A. Kozimor, R.L. Martin, D.K. Shuh, T. Tyliszczak, L.J. Vernon, J. Am. Chem. Soc. 135(39) (2013) 14731-14740. [44] J.L. Kiplinger, D.E. Morris, B.L. Scott, C.J. Burns, Organometallics 21(15) (2002) 3073-3075.

[45] K.C. Jantunen, C.J. Burns, I. Castro-Rodriguez, R.E. Da Re, J.T. Golden, D.E. Morris, B.L. Scott, F.L. Taw, J.L. Kiplinger, Organometallics 23(20) (2004) 4682-4692. [46] E.J. Schelter, P. Yang, B.L. Scott, R.E. Da Re, K.C. Jantunen, R.L. Martin, P.J. Hay, D.E. Morris, J.L. Kiplinger, Journal of the American Chemical Society 129(16) (2007) 5139-5152.

[47] E.J. Schelter, P. Yang, B.L. Scott, J.D. Thompson, R.L. Martin, P.J. Hay, D.E. Morris, J.L. Kiplinger, Inorganic Chemistry 46(18) (2007) 7477-7488. 


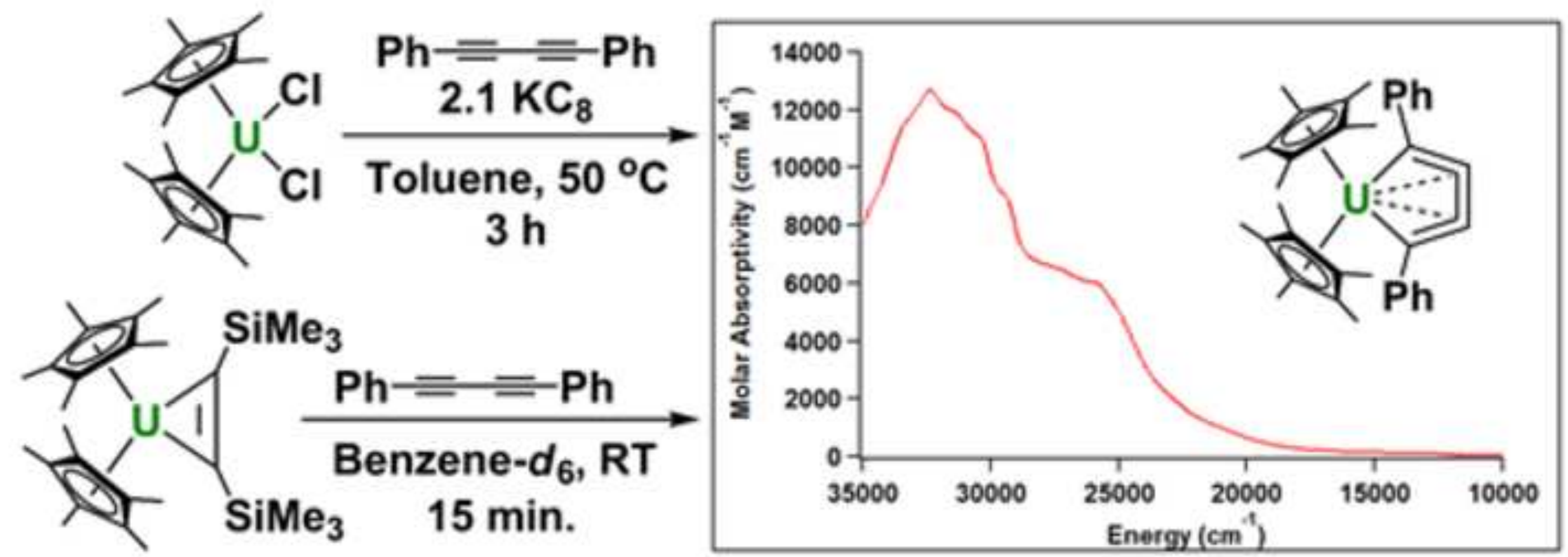

